
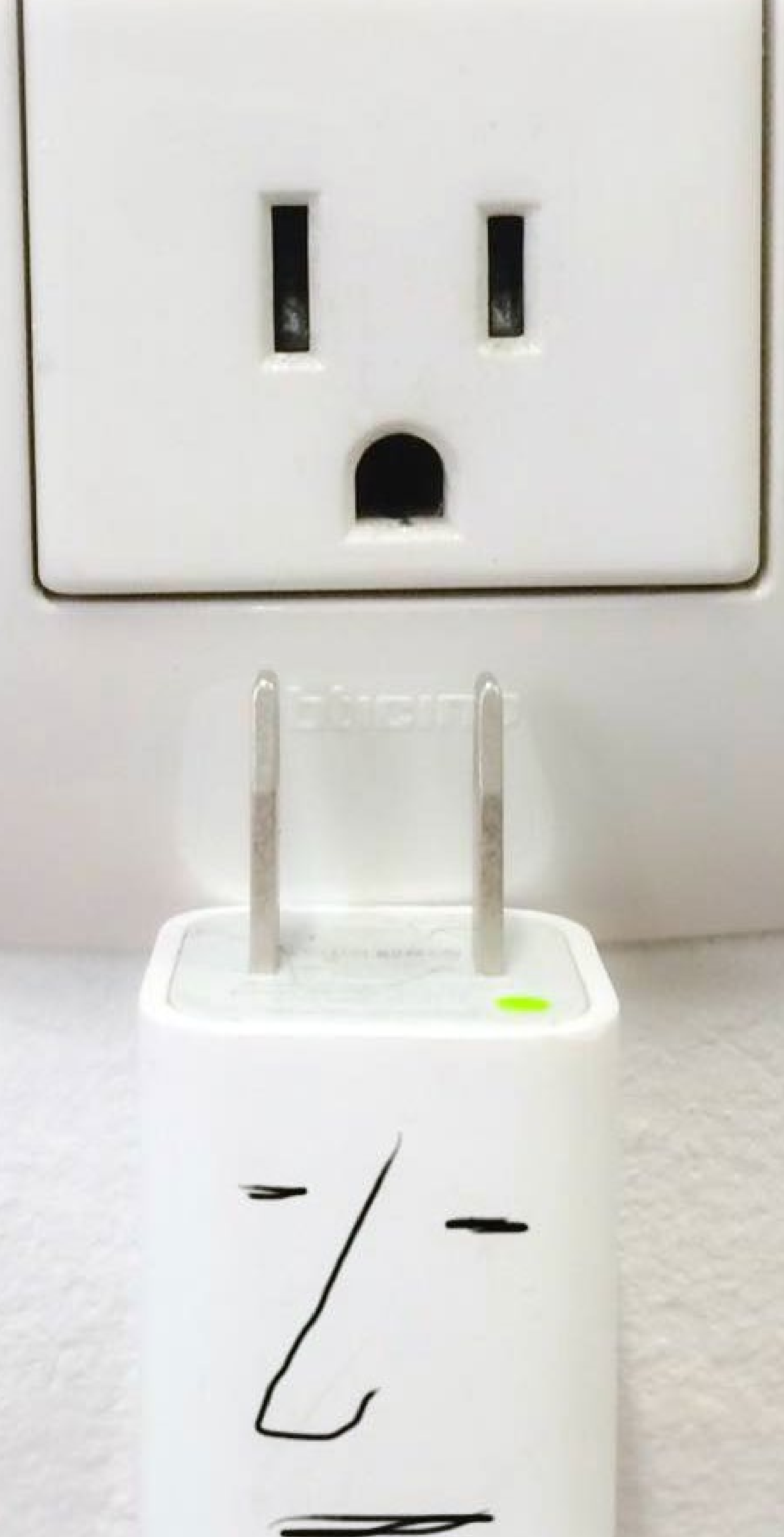


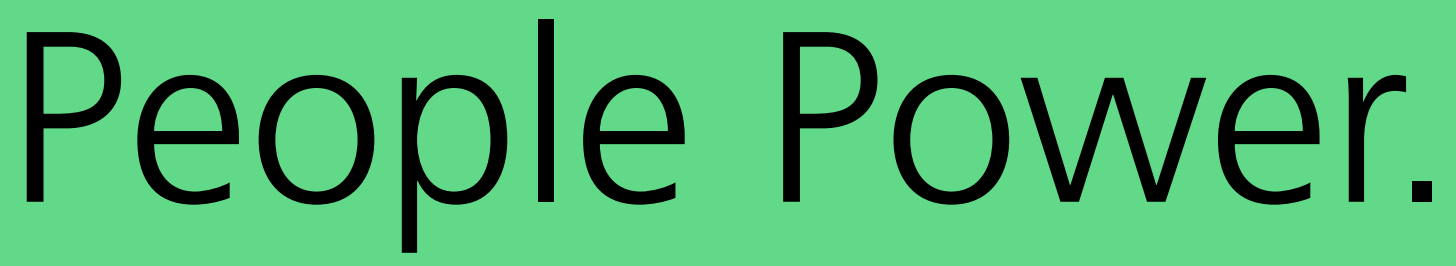

Supporting

Activities with

a Social Benefit

Edward Gardiner 


\title{
People Power. Supporting Activities with a Social Benefit
}

\section{Edward Gardiner'}

\begin{abstract}
Many people around the world are taking action to address the problems that matter to them and their community, from anti-social behaviour to unaffordable healthcare to institutional corruption. Many more people have the potential to make a difference in their community. Their collective knowledge, skills, abilities and personal attributes are the building blocks of social change. While there is a growing emphasis on the role of disciplines such as design, behavioural science and digital technology in social innovation, people need to develop and exchange a range of attributes to understand problems and implement ideas. In this article I review some of the individual and environmental factors that are predictive of creative performance and entrepreneurial success, and highlight areas of opportunity for how to help more people get involved in activities with a social benefit.
\end{abstract}

Keywords | Creativity; Entrepreneurship; Social change; Community; Social design

1 Warwick Business School, University of Warwick, Coventry, CV4 7AL, United Kingdom. edward.gardiner@wbs.ac.uk 


\section{Resumen}

Muchas personas alrededor del mundo están tomando medidas para hacer frente a los problemas que son importantes para ellos y su comunidad, a partir del comportamiento antisocial a la asistencia sanitaria fuera del alcance de la corrupción institucional. Muchas más personas tienen el potencial de hacer una diferencia en su comunidad. Sus conocimientos colectivos, destrezas, habilidades y atributos personales son los bloques de construcción del cambio social. Si bien existe un creciente énfasis en el papel de disciplinas como el diseño, la ciencia del comportamiento y de la tecnología digital en la innovación social, la gente necesita para desarrollar e intercambiar una serie de atributos para entender los problemas y poner en práctica las ideas. En este artículo se revisan algunos de los factores individuales y ambientales que son predictivos del rendimiento creativo y el éxito empresarial, y ponen de relieve las áreas de oportunidad para la forma de ayudar a más personas se involucren en actividades de beneficio social.

Palabras clave | Creatividad; Emprendimiento; Cambio social; Comunidad; Diseño social 


\section{Introduction}

Solving complex, novel, ill-defined problems requires people to think and act creatively but individual talent alone is not enough and the potential people have will only lead to action under conditions that are supportive of creativity and entrepreneurship. Success is a product of both individual potential and environmental context.

Furthermore, the results of one individual's actions are often dependent on the actions of another. To work effectively together, people must coordinate their actions to achieve their own and common goals (Malone \& Crowston, 1994). A failure to coordinate can lead to wasted effort and potential, and suboptimal outcomes for society.

A lot has been written and done from a policy, academic and practical perspective to enable and encourage people to become more active in their community. The result is plenty of variation in terminology, approach and evidence of what works. This review unites some of the research and practice, and poses a set of questions for what might help more people get involved in activities with a social benefit.

I start by outlining some of the individual factors that are predictive of creative performance and entrepreneurial success, followed by the environmental factors, or market conditions, that effect whether people become actively involved in social change. I finish by highlighting some questions for how to help more people take action to improve the world for others.

\section{Individual potential}

The knowledge, skills, abilities and personal attributes that people possess are often referred to as human capital and are largely the product of education and experience (Ployhart \& Moliterno, 2011). Growing human capital is predictive of entrepreneurial success (Unger, Rauch, Frese, \& Rosenbusch, 2011). The human capital people need to understand a problem or implement an idea varies depending on the circumstance. Different people have different attributes that may be relevant to the same problem or idea but no one has all the relevant attributes. People must engage in an exchange to acquire or develop the 
necessary human capital. To inform different types of support, we need to understand the individual potential of people in the market and the attributes they need.

\section{Knowledge}

Theoretical knowledge refers to knowledge of facts and concepts, for example knowing that Mexico City is the capital of Mexico, or that social justice is the idea that everyone deserves equal social and political rights. It can be easily articulated, recorded and transferred in books, films and online. Our ability to access and use this knowledge is known as expertise.

Some people have deep knowledge of specific domains, for example of human decisionmaking and behaviour, while others have a broad knowledge base of multiple subjects. People with both depth and breadth are believed to be more likely to make the connections necessary to generate novel ideas (Hansen \& Nohria, 2004).

Practical knowledge refers to knowledge of how to perform a task or process, for example how to ride a bike or socialise at events. It can be hard to verbalise and write down, and is often transferred through instruction, practice, imitation and observation.

Knowledge of what to do and how to do something is not just knowledge of the facts of how to do it, and someone who knows how to do something does not necessarily know all the facts. People who are self-taught are often unaware of the knowledge they have and its value to others, while people who aspire to do something may have all the facts but no opportunity to learn.

Experiential knowledge refers to knowledge of an event or subject gained through experience and personal interaction. Empathy is the experience of understanding or feeling what another person is experiencing (Baron-Cohen \& Wheelwright, 2004). Compassion refers to when these feelings and thoughts include the desire to help when people are confronted with another's suffering or misfortune. 
People who wish to address problems or implement ideas in a community need intimate knowledge of the culture, life and emotion of the area (VanSandt, Sud, \& Marme, 2009). These experiences will be second nature to people who are developing initiatives in their own community but people without first hand experience may struggle to empathise with the feelings that cause people to make certain decisions or champion a particular cause.

There are many ways the people coordinate to exchange different types of knowledge with different goals in mind. Websites like Wikipedia, Quora and Change.org consolidate answers and opinions from multiple individuals; platforms like eHow, Instructables.com, and Coursera help people share practical guidance; and online data from platforms like Twitter and Google is increasingly being used to predict real world issues (Eichstaedt, et al., 2015).

Digital technology has revolutionised how people access theoretical knowledge but barriers to access have become barriers to use. People who aspire to do something may have all the facts but no opportunity to learn how to perform the tasks involved or no experience of the issues at hand. What might help people better coordinate and exchange practical knowledge, or better understand and learn from experiential knowledge?

\section{Skills}

Domain specific, or technical skills, are the skills required to complete a specific job or task. For example, painters must be able to use a brush and programmers must be able to code. Carpenters, engineers, teachers and nurses are all examples of workers with specialist skills.

People need a range of skills to conceptualise and develop ideas in order to apply their knowledge and learn from the results. Some techniques could be considered core skills, for example the skill to draw and visualise ideas. Design methods are increasingly being seen as core skills in public and social innovation, particularly to help people understand user experiences and prototype ideas (Mulgan, 2014). 
Domain general skills are skills more broadly needed across a particular domain. Creativity is associated with a range of general processing skills that can be aligned to stage models of the creative process (Hunter, Cushenbery, \& Friedrich, 2012), for example, the 'eight-stage model' (Mumford, Mobley, Reiter-Palmon, Uhlman, \& Doares, 1991) and the 'six stages of innovation' (Murray, Caulier-Grice, \& Mulgan, 2010). Both loosely cover problem identification, idea generation, implementation and monitoring. While creativity is often perceived as all or nothing, creative problem solving skills can be taught (Eubanks, Murphy, \& Mumford, 2010) and not everybody will be - or needs to be - skilled at every stage.

There are many initiatives that help people develop the skills to conceptualise their ideas by developing technical skills or accessing training and equipment. Community workshops like TechShop in the USA provide members with tools, equipment and classes; services like Codeacademy help people learn to program for free; and resources like the IDEO Human Centred Design Toolkit and Nesta DIY Toolkit help people think and act creatively.

All of these initiatives involve people actively learning the skills to perform tasks and implement ideas but technical or vocational subjects are often divided from academic subjects. The result is a gap between people who hold knowledge and people with the skill to apply their knowledge. What might help more people develop the technical and problem-solving skills they need to succeed in a particular domain?

\section{Abilities}

Cognitive ability refers to how well people can understand, interpret, retain and use information. Cognitive ability is multidimensional however the different abilities are positively related (Mackintosh, 2011). General cognitive ability is known as intelligence and measured using IQ tests. The relationship between creativity and intelligence has been debated for decades.

One idea is that intelligence is not a sufficient precursor to creativity (Runco, 2014), and that specific abilities are better predictors of creative achievement, for example, divergent 
thought - the ability to explore many possible solutions (Kim, 2008); associational ability - the ability to make connections between remote concepts; and analogical ability - the ability to recognise similarities between different types of problem (Welling, 2007). There is a fine line between skills and abilities and many creative toolkits like those mentioned above do not delineate between them.

\section{Personality and motivation}

Personality refers to a set of traits that characterise individual differences in how people think, feel and behave. Personality is normally broken down into the 'Big Five' dimensions: neuroticism, extraversion, openness, agreeableness and conscientiousness (Digman, 1990). These traits influence the intentions and the manner in which people act as an entrepreneur (Nga \& Shamuganathan, 2010).

In general, "creative people are more open to new experiences, less conventional and less conscientious, more self-confident, self-accepting, driven, ambitious, dominant, hostile, and impulsive" (Feist, 1998, 290). People with creative personalities are also more likely than others to identify business opportunities and start businesses (Shane \& Nicolaou, 2015). Creative people sometimes have a reputation for being disruptive however they are generally more open and flexible to new experiences.

Motivation is an internal state that drives people into action and is directed towards the satisfaction of needs. Motivation can be divided into intrinsic motivation, when someone is driven by an interest or desire in the task itself, and extrinsic motivation, when someone performs an activity to obtain a desired outcome, for example a financial reward (Benabou \& Tirole, 2003). People who are passionate about a particular cause or idea are often responding to a personal struggle or experience. High levels of intrinsic motivation are related to creative achievement because passion can help people overcome the inherent difficulties with novel implementation. People who are driven by recognition and being part of the intellectual fashion may be more likely to stop once the glamour is gone or the work gets harder. 
There are many initiatives that encourage curiosity and help people find out what they like. Many universities run taster courses to introduce people to different subjects outside their specialty; the d.school at Stanford University runs a course called LaunchPad during which people start and incorporate a company in three months; and organisations like Escape the City in the UK help people transition from one sector to another.

Many people now have two, three or four careers during their lifetime rather than settling on one career of industry. A demand for more socially-minded jobs and the diversity of careers available mean organisations must understand, manage and accept changes in purpose and motivation over time. What might help people determine their purpose in life and develop the characteristics they desire?

\section{Environmental context}

Environmental context refers to the physical and social setting in which people live, work and learn, and the people and places with which they interact. In the market for human capital, the environmental context refers to the market conditions, or characteristics, of the related sectors that effect people who wish to engage in an exchange. To help people cooperate and work effectively together, we need to understand the environmental factors that effect how well the market functions.

\section{Social expectation}

Whether or not people believe they have the characteristics and capacity to fulfil the role of being creative and entrepreneurial is critical to driving action (Farmer, Yao, \& KungMcintyre, 2011). Identity influences people's intentions and motivation to act (Murnieks \& Mosakowski, 2007), while self-efficacy influences factors such as level of effort, perseverance, and resilience in the face of obstacles, adversity or failure (Bandura, 1997). Without them, little will happen.

The problem is reality does not always reflect the range of characteristics and tasks associated with creativity and entrepreneurship. A real or perceived lack of diversity among those 
calling themselves entrepreneurs or accessing resources means that people often misperceive the social expectation of what it means to be entrepreneurial, fail to recognise their own entrepreneurial attributes or lack confidence in their ability to create change. Observing similar people successfully perform a task, constructive feedback, group membership and celebrating achievements can help build self-efficacy.

There are many examples of initiatives that aim to help people reflect on their identity and grow self-efficacy. The Gallup Strengths Finder helps people understand their combination of strengths and entrepreneurial talents; the BuzzFeed 'which character are you' quizzes playfully let people identify with a character in a particular show; and there are many coaching programmes that support the transfer of skills between like-minded individuals.

People who are classified as 'hard to reach' are often actually marginalised by existing support. Programmes must be designed inclusively so that people understand and identify with the characteristics that are important at different stages. However, designing programmes that explicitly target underrepresented groups may further stigmatise their role (Fletcher, 2005). What might help people identify and grow belief in their capacity to create change?

\section{Availability of resources}

Resources refer to goods and services in the form of money, materials and staff that people use to function effectively. Financial resources, for example grants, investments and prizes, are the most well served area of provision for social ventures but are not always the most important. Non-financial resources include equipment, training and space, offered by sellers to support creativity and entrepreneurship.

In general, the support available does not reflect the diversity of knowledge, skills, abilities and traits that are predictive of creative performance and entrepreneurial success. Most training programmes focus on developing traditional business and strategy skills. The result 
is a small number of providers serving a limited number of people for a short period of time. People need open access to more targeted and timely assistance when they are faced with specific challenges or problems (Mole, Hart, Roper, \& Saal, 2009).

There are now many examples of collaborative consumption that reduce market power and enable the redistribution and sharing of resources (Schlafman, 2014). People redistribute goods using services like eBay and Freecycle; raise funds on platforms like Kickstarter and Spacehive; request a minicab using Uber; create software on GitHub; find a room on Airbnb; and the list goes on.

The sharing economy and models of collaborative consumption have revolutionised these sectors and are a product of enhanced information disclosure and ease of interaction. Each service relies on trust and the will of people to share, leading to cost savings, stronger communities and increased participatory democracy. There are currently a small number of organisations, labs, programmes and places that provide resources to support community enterprise around the world (Nesta, 2015). What might help people redistribute and share access to the resources they need, when they need them?

\section{Flow of information}

Flow of information refers to the transfer of information from one person to another about the goods and services available. In a perfect market, there is no information failure or time lags and knowledge is freely available to everybody in the market. People who are in a supportive environment, whether it's where they live, work or learn, may be more likely to think and act creatively because they have access to the information and support networks to share and redistribute resources (Mathiesen \& Einarsen, 2004).

Collectives are gatherings of people from different backgrounds with a common goal. They can assume many forms, including social movements, community cooperatives and cross-sectorial collaborations. The main activities include framing - interpreting opportunities to mobilise people; convening - bringing together disparate groups of people; and 
consolidation - considering and understanding multiple voices and lenses (Montgomery, Dacin, \& Dacin, 2012).

Different types of environment can help or hinder the flow of information. Organisational and leadership structures are designed to allocate tasks and support; people use networking services like Meetup or community spaces to find and meet others with shared interests; international organisations like the UNHCR work with specific populations of refugees to support bottom-up innovation (Betts, Bloom, \& Weaver, 2015); and there are many associations, groups and networks united by a common interest.

People who share the same environment often develop a sense of solidarity and trust that can strengthen their resolve in the face of problems or uncertainty. People who don't work, who work more independently or who are part of a bureaucratic organisation may not have the opportunity to benefit from being part of a collective or may find themselves isolated from supportive networks. What might help people interact and share information to pursue a common goal? 


\section{Conclusion}

This review only scratches the surface of research on creativity and entrepreneurship. What it highlights is the diversity of knowledge, skills, abilities and other personal attributes that people need to understand problems and implement ideas depending on the circumstance, and some of the environmental factors that may effect whether people become active in their community. While it is important to promote the importance of certain disciplines within this process, for example design, behavioural science and digital technology, there is a fundamental need to help people coordinate their actions to work effectively together.

Based on the evidence and questions presented above, I believe there are three core aims that must be achieved to help more people get involved in activities with a social benefit. We must 1) enable people to exchange the knowledge and resources required to understand complex problems or implement novel ideas; 2) help people develop the skills, abilities and traits related to creative achievement and entrepreneurial success and 3) provide an opportunity for people to understand, recognise and grow belief in how they can improve the world for others. Fulfilling these aims is not the responsibility of a small number of individuals and institutions. Everyone has a role to play in creating social change. 


\section{References}

Bandura, A. (1997). Self-efficacy: The exercise of control. New York: Macmillan.

Baron, R. A., \& Markman, G. D. (2000). Beyond social capital: How social skills can enhance entrepreneurs' success. The Academy of Management Executive, 14(1), 106-116.

Baron-Cohen, S., \& Wheelwright, S. (2004). The empathy quotient: an investigation of adults with Asperger syndrome or high functioning autism, and normal sex differences. Journal of autism and developmental disorders, 34(1), 163-175.

Benabou, R., \& Tirole, J. (2003). Intrinsic and extrinsic motivation. The Review of Economic Studies, 70(3), 489-520.

Betts, A., Bloom, L., \& Weaver, N. (2015). Refugee Innovation: Humanitarian innovation that starts with communities. Oxford: University of Oxford Refugee Studies Centre.

Digman, J. M. (1990). Personality structure: Emergence of the five-factor model. Annual review of psychology, 41(1), 417-440.

Eichstaedt, J. C., Schwartz, H. A., Kern, M. L., Park, G., Labarthe, D. R., Merchant, R. M., Weeg, C. (2015). Psychological language on twitter predicts countylevel heart disease mortality. Psychological science, 26(2), 159-169.

Eubanks, D., Murphy, S. T., \& Mumford, M. D. (2010). Intuition as an influence on creative problem-solving the effects of intuition, positive affect, and training. Creativity Research Journal, 22(2), 170-184.

Farmer, S. M., Yao, X., \& Kung-Mcintyre, K. (2011). The behavioral impact of entrepreneur identity aspiration and prior entrepreneurial experience. Entrepreneurship Theory and Practice, 35(2), 243273.

Feist, G. J. (1998). A meta-analysis of personality in scientific and artistic creativity. Personality and Social Psychology Review, 2(4), 290-309.
Fletcher, D. (2005). Providing enterprise support for offenders: realising new opportunities or reinforcing old inequalities? Environment and Planning C: Government \& Policy, 23(5), 715-731.

Hansen, M. T., \& Nohria, N. (2004). How to build collaborative advantage. MIT Sloan Management Review, 46(1), 22.

Hunter, S. T., Cushenbery, L., \& Friedrich, T. (2012). Hiring an innovative workforce: A necessary yet uniquely challenging endeavor. Human Resource Management Review, 22(4), 303-22.

Kim, K. H. (2008). Meta-Analyses of the Relationship of Creative Achievement to Both IQ and Divergent Thinking Test Scores. The Journal of Creative Behavior, 42(2), 106-130.

Mackintosh, N. (2011). IQ and human intelligence. Oxford: Oxford University Press.

Malone, T. W., \& Crowston, K. (1994). The interdisciplinary study of coordination. ACM Computing Surveys (CSUR), 26(1), 87-119.

Mathiesen, G. E., \& Einarsen, S. (2004). A review of instruments assessing creative and innovative environments within organizations. Creativity Research Journal, 16(1), 119-140.

Mole, K. F., Hart, M., Roper, S., \& Saal, D. S. (2009). Assessing the Effectiveness of Business Support Services in England Evidence from a Theory-Based Evaluation. International small business journal, 27(5), 557-582.

Montgomery, A. W., Dacin, P. A., \& Dacin, M. T. (2012). Collective social entrepreneurship: Collaboratively shaping social good. Journal of Business Ethics, $111(3), 375-388$.

Mueller, J. S., Melwani, S., \& Goncalo, J. A. (2012). The bias against creativity: why people desire but reject creative ideas. Psychological science, 23(1), 13-17. 
Mulgan, G. (2014). Design in public and social innovation. London: Nesta.

Mumford, M. D., Mobley, M. I., Reiter-Palmon, R., Uhlman, C. E., \& Doares, L. M. (1991).

Process analytic models of creative capacities. Creativity Research Journal, 4(2), 91-122.

Murnieks, C., \& Mosakowski, E. (2007). Who am I? looking inside the'entrepreneurial identity. Frontiers of Entrepreneurship Research.

Murray, R., Caulier-Grice, J., \& Mulgan, G. (2010). The open book of social innovation. London: Nesta.

Nesta. (2015, May 19). World of Labs. Retrieved from Nesta: Retrieved from: nesta.org.uk/blog/world-labs

Nga, J. K., \& Shamuganathan, G. (2010). The influence of personality traits and demographic factors on social entrepreneurship start up intentions. Journal of Business Ethics, 95(2), 259-282.doi:10.1007/ s10551-009-0358-8

Ployhart, R. E., \& Moliterno, T. P. (2011). Emergence of the human capital resource: A multilevel model. Academy of Management Review, 36(1), 127-150.

Runco, M. A. (2014). Creativity: Theories and themes: Research, development, and practice. London: Elsevier.

Schlafman, S. (2014, April 4). Uberification of the US Service Economy. Retrieved from Mindful VC: schlaf.me/post/81679927670

Shane, S., \& Nicolaou, N. (2015). Creative personality, opportunity recognition and the tendency to start businesses: A study of their genetic predispositions. Journal of Business Venturing, 30(3), 407-419.

Unger, J. M., Rauch, A., Frese, M., \& Rosenbusch, N. (2011). Unger, J. M., Rauch, A., Frese, M., \& Rosenbusch, N. (2011). Human capital and entrepreneurial success: A meta-analytical review. Journal of Business Venturing, 26(3), 341-358.
VanSandt, C. V., Sud, M., \& Marme, C. (2009). Enabling the original intent: Catalysts for social entrepreneurship. Journal of Business Ethics, 90(3), 419-428.

Welling, H. (2007). Four mental operations in creative cognition: The importance of abstraction. Creativity Research Journal, 19(2-3), 163-177.

Yi, S. K., Steyvers, M., Lee, M. D., \& Dry, M. J. (2012). The wisdom of the crowd in combinatorial problems. Cognitive Science, 36(3), 452-470. 